\title{
A mappingtechnikák által nyújtott lehetöségek a szív-MR-vizsgálatok során: indikációk, diagnosztikus érték, limitációk és centrumunk kezdeti tapasztalatai
}

\author{
Hirschberg Kristóf', Dohy Zsófia', Tóth Attila1, Szabó Liliána', \\ Czimbalmos Csilla', Finster Marius', Suhai Ferenc1, “Merkely Béla1, ‘Vágó Hajnalka' \\ *megosztott utolsó szerzők \\ ${ }^{1}$ Semmelweis Egyetem, Városmajori Szív- és Érgyógyászati Klinika, Budapest
}

Levelezési cím:

Dr. Hirschberg Kristóf PhD, 1122 Budapest, Városmajor utca 68., E-mail: hirschbergkristof@gmail.com

\begin{abstract}
Az Európai Kardiológiai Társaság (ESC) aktuális irányelveiben számos kórkép tekintetében a szív mágnesesrezonancia-(MR) vizsgálata mára a diagnosztika szerves részét képezi. Sok esetben más módszerrel nem pótolható információt nyújt a szívMR (pl. akut myocarditis, akut miokardiális infarktus szignifikáns koszorúér-betegség nélkül, ritka cardiomyopathiák, veleszületett szívbetegségek). Más esetekben pedig megerősíti az iránydiagnózist, illetve kiegészíti egyéb információkkal (pl. dilatatív cardiomyopathia, hipertrófiás cardiomyopathia, infarktusos hegek stb.). A növekvő igénnyel szemben áll a korlátozott hozzáférhetőség, a magas költség és bizonyos kontraindikációk is. Ezért kívánatos, hogy a jövőben szélesebb körben elérhető és gyorsabb szív-MR-vizsgálatokra legyen lehetőség, minél több információhoz jussunk egy-egy vizsgálattal, és adott esetben kontrasztanyag nélkül is elvégezhetö legyen. Számos, a közelmúltban kifejlesztett új MR-szekvencia is utat nyithat ebbe az irányba. Többek között az ún. mappingtechnikák, amelyek segítségével kontrasztanyag nélkül kaphatunk információt a szívizom összetételéröl, a különböző patológiás folyamatban kulcsszerepet játszó ödémáról és fibrózisról. A mappingnek alig több mint egy évtizedes múltja van, ez idő alatt pedig számos irodalmi adat látott napvilágot. A Városmajori Szív- és Ėrgyógyászati Klinikán tavaly nyáron bevezetett mappingtechnikák alapjait tárgyalja ez az összefoglaló közlemény, és kitér az eddig szerzett tapasztalatokra is. Szemléltető példákon keresztül mutatja be a legfontosabb klinikai indikációkat, diagnosztikus értéküket és a fontosabb limitációkat.
\end{abstract}

Kulcsszavak: szív-MR, kontrasztanyag, mapping, fibrózis, cardiomyopathia

The potential of mapping techniques in cardiac magnetic resonance imaging: Indications, diagnostic value, limitations and first experience in our center

Cardiac magnetic resonance imaging (CMR) is an essential part of noninvasive diagnostics in cardiology according to several current guidelines of the European Society of Cardiology (ESC). In many cases, CMR provides unique information on cardiac pathology which cannot be replaced by other methods (e.g. in acute myocarditis, myocardial infarction with non-obstructive coronary arteries, rare cardiomyopathies, takotsubo syndrome, congenital heart diseases). In other cases, CMR confirms or completes a suspected diagnosis (e.g. dilatative cardiomyopathy, hypertrophic cardiomyopathy, infarct scars etc.). A widespread use is limited - despite the increasing needs - by the restricted availability, the high costs and some contraindications as well. Thus, a better availability and faster CMR examinations that provide even more information would be welcome. A contrast-agent free approach would also be beneficial. Some of the newly developed CMR sequences could clear the way for this purpose. Among others, so called mapping techniques are able to characterise myocardial tissue for edema and fibrosis. Both are very important in diverse pathological conditions. Mapping is a relatively new technique with a history of about a decade and with already a huge literature, partly with different aspects. Mapping is available since last summer at the Semmelweis University Heart and Vascular Center. This review work describes the theoretical basis of mapping techniques and the on-site experiences by the beginning of 2020. Some representative cases are presented in order to introduce the clinical applications, indications, diagnostic value and limitations of different mapping techniques.

Keywords: CMR, contrast agent, mapping, fibrosis, cardiomyopathy 


\section{Bevezetés}

A szív mágneses rezonanciás vizsgálata (szív-MR) a legfontosabb képalkotó módszer azokban az esetekben, amikor felmerül a szívizmot érintő strukturális eltérés gyanúja, azonban az anamnézist, EKG-t, laborvizsgálatokat, echokardiográfiát, terheléses teszteket, koronarográfiát, esetleg szívizom-biopsziát magába foglaló diagnosztika nem szolgáltat elegendő információt, és a vizsgálatnak terápiás konzekvenciája is van. Tekintve a vizsgálatok időigényességét, illetve a korlátozott hozzáférést, fontos az indikáció megfelelő felálí́tása, a precíz kérdésfelvetés és az esetleges kontraindikációk mérlegelése.

Az Európai szív-MR-regiszter közelmúltban publikált adataiból láthatjuk a leggyakoribb indikációkat egy nagyszámú betegpopuláció alapján (1. táblázat) (1). Az adatokat tanulmányozva kitűnik, hogy a vizsgálatok egy jelentős része a szívizmot érintő különböző károsodások etiológiájának tisztázására irányul (pl. myocarditis, cardiomyopathia gyanúja, koszorúér-betegséggel összefüggő szívizom-károsodások, viabilitás kérdése). Jellegzetes példaként említhető az ismeretlen eredetű balkamra-hipertrófia, a pumpafunkció-csökkenés vagy a regionális falmozgászavar etiológiájának tisztázása. Olyan, a terápiát alapvetően befolyásoló diagnózisok is születhetnek, amelyek más módszerrel nehezen vagy nem megbízhatóan lettek volna felfedhetőek (pl. MINOCA - Myocardial Infarction with Non-obstructive Coronary Arteries, ritkább cardiomyopathiák vagy kardiális sarcidosis) (2).

Mindezen kérdések megválaszolásához esszenciális a late gadolinium enhancement (LGE, késői kontrasztanyag-halmozás) szekvenciák alkalmazása, amelynek röviden megfogalmazott lényege, hogy a különböző okokból károsodott szívizomból a gadolíniumtartalmú kontrasztanyag lassabban mosódik ki, mint az ép myocardiumból. A szövetek mágneses tulajdonságának

1. TÁBLÁZAT. Szív-MR-vizsgálatok indikációi az európai szív-MR-regiszter adatai alapján

Szív-MR-vizsgálatok indikációi

\begin{tabular}{|c|c|c|}
\hline Myocarditis/cardiomyopathiák & $32,2 \%$ & $\begin{array}{r}8950 / \\
27767\end{array}$ \\
\hline $\begin{array}{l}\text { Koronáriabetegség gyanúja, illetve } \\
\text { iszkémia ismert koronáriabetegség } \\
\text { esetén }\end{array}$ & $34,2 \%$ & 9508 \\
\hline Szívizom-viabilitás & $14,6 \%$ & 4048 \\
\hline Billentyübetegségek & $5,4 \%$ & 1495 \\
\hline Aortabetegség & $3,7 \%$ & 1026 \\
\hline Congenitális szívbetegség & $2,2 \%$ & 624 \\
\hline Kamrai thrombus & $1,2 \%$ & 330 \\
\hline Szívtumorok & $1,0 \%$ & 288 \\
\hline Tüdőerek & $1,0 \%$ & 282 \\
\hline Koszorúerek & $0,2 \%$ & 57 \\
\hline Minden egyéb & $10,7 \%$ & 2963 \\
\hline
\end{tabular}

megváltoztatásával a károsodás vizualizálható, amelyek különböző mintázatai általában jellegzetesek egyegy betegségre. Miokardiális infarktusban tipikusan az endocardiumtól kiinduló, az epicardium felé terjedő, a falvastagság különböző érintettségével járó késői halmozást látunk. Myocarditisben szubepikardiálisan kezdődő, de midmiokardiálisan is előforduló késői halmozás lehetséges, DCM-ben midmiokardiális, HCM-ben pedig a hipertrófizált szegmentumokban, az inzerciós pontokban jellegzetes a késői halmozás, de a normális szegmentumokban is jelen lehet. Miokardiális tárolási betegségekben diffúz halmozás a jellemző $(3,4)$. Egyes esetekben a kép nem ilyen egyértelmü, és a rutint kiegészítő szekvenciák, síkok alkalmazása lehet szükséges. Fontos a nagy tapasztalattal bíró vizsgáló, és adott esetben további, még fejlesztési stádiumban lévő felvételekből származó információk felhasználása is szóba jöhet.

Újabban léteznek kontrasztanyag adását nem igénylő MR-technikák, amelyek szintén a szívizom tulajdonságainak jellemzésére alkalmasak. Ide tartoznak a mappingtechnikák, amelyeknek kardiológiai klinikai alkalmazását mintegy másfél évtizede írták le először, és amely azóta is folyamatos fejlesztés és kutatás tárgyát képezi világszerte (5). A téma hazai aktualitását adja, hogy ezek a szekvenciák egyre több centrumban már elérhetőek, többek között a Városmajori Szív- és Érgyógyásztati Klinikán 2019 májusa óta az 1,5 teslás Siemens Aera szkenneren.

A következőkben a mapping elvének megértéséhez szükséges fizikai alapokról, majd a mappingtechnikák elméleti és gyakorlati alkalmazásáról írunk. Szó lesz a Nemzetközi Szív- és Érrendszeri Mágneses Rezonancia Társaság (SCMR) mappingre vonatkozó ajánlásairól, valamint néhány saját eseten keresztül bemutatjuk a $T_{1}$-mapping klinikai használatát. Részben érintjük a $T_{2}$-mappinget és az extracelluláris tér (ECV) mappingjét is.

A mappingtechnikák fontosságát több tényező támasztja alá. Egyrészt enyhébb, diffúz szívizom-károsodással járó betegségek a hagyományos LGE-technikával adott esetben nem detektálhatóak. Másrészt kívánatos a szív-MR-protokollok rövidítése a költséghatékonyság és szélesebb hozzáférhetőség érdekében, amelyet a kontrasztanyag nélküli vizsgálatok jóval kisebb időigénye lehetővé tehet (6). Utóbbi azonban csak megfelelően szűrt betegcsoportban lehetséges, mert jelenleg a szív-MR-vizsgálatok nagy részében még elengedhetetlen a kontrasztanyag alkalmazása (1).

\section{Az MR-képalkotás alapjai}

Ebben a részben mindössze annyit tekintünk át az MR-fizikából, amennyi a mapping könnyebb megértéséhez feltétlenül szükséges (7-10). A vizsgált testrészt egy mesterségesen létrehozott erős, szupravezető elektromágnes által fenntartott, statikus (állandó) mág- 


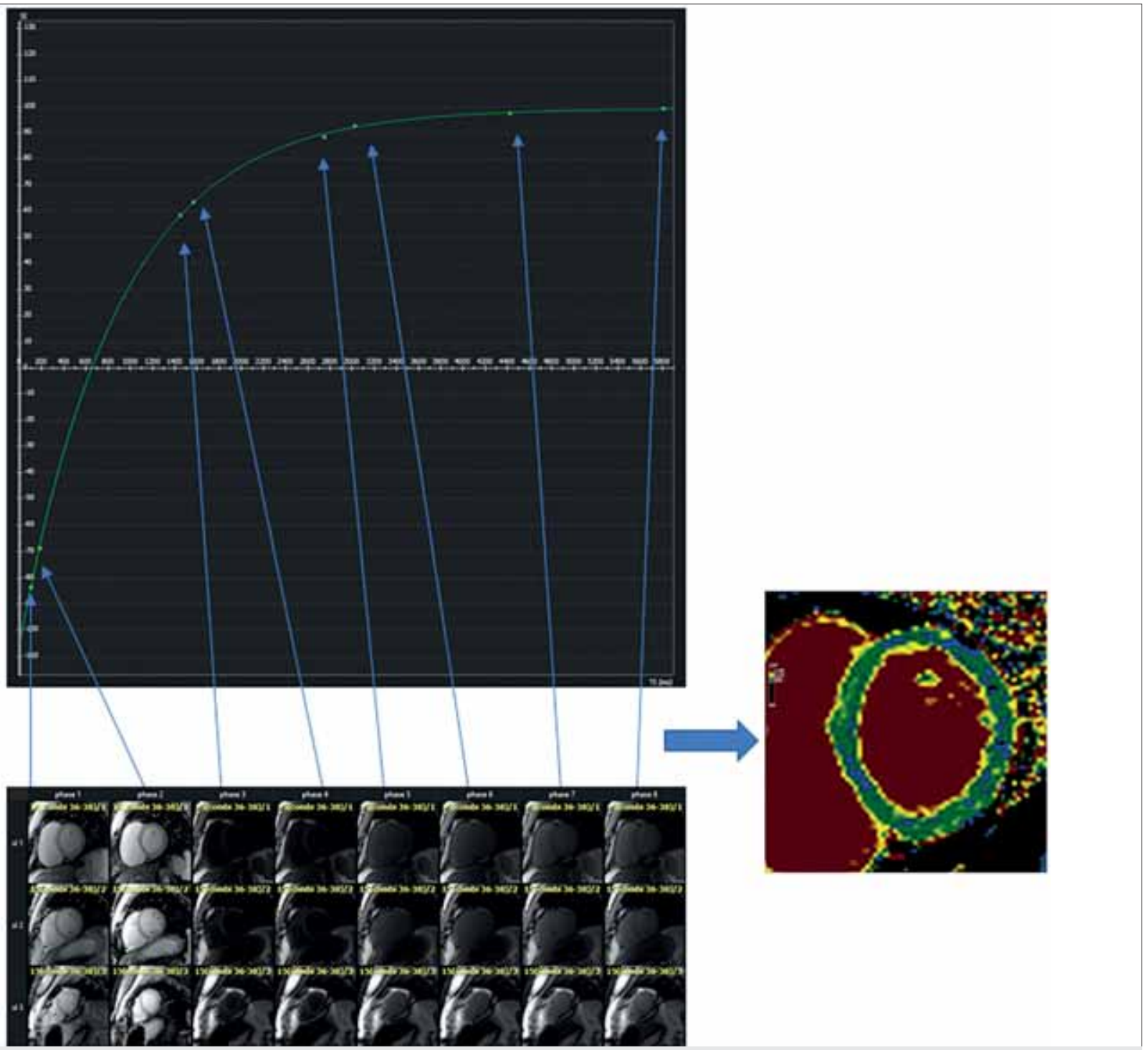

1. ÁBRA. $T_{1}$-relaxációs görbe egészséges myocardiumban, illetve a $T_{1}$-mapping előállításának elve

neses térbe helyezik, ahol a szövetekben nagy számban jelenlévő hidrogénatomok protonjai parallel vagy antiparallel irányba rendeződnek, amely egy kicsi, de mérhető nettó mágnesezettséget eredményez. Mivel az emberi test mintegy $70 \%$-a vízből áll, a maradék pedig számottevő részben zsír, ezért nagy számban vannak jelen hidrogénatomok. Mivel a hidrogén páratlan protonszámú, és párosítatlan spinnel rendelkezik, mágneses tulajdonsága van: ezért a hidrogén a legalkalmasabb a mérésre. A protonokat külső, ultrarövid rádióhullám-impulzusokkal (URH) gerjeszik, majd ennek kikapcsolása után a protonok az eredeti állapotba való visszatérés (relaxáció) során rádióhullámokat sugároznak vissza. Ezt antennákkal (tekercsekkel) detektálja a berendezés, és a jeleket bonyolult matematikai algoritmusok segítségével az MR (Fourier-transzformáció újabban wavelettranszformáció) végül képpé alakítja. Az állandó mágneses tér mellett használt további mágneses terek, ún. gradiens mezők (tekercsek) alkalma- zásával térben ki lehet választani az aktuális mérések helyét.

Megkülönböztetjük a longitudinális és a transzverzális relaxációt. A rendezetlenül pörgő hidrogéndipólusok kicsivel nagyobb része áll be parallel, mint antiparallel irányba a szupravezető mágnesben, amely longitudinális mágnesezettséget okoz. A rádióhullám-impulzusokkal történő gerjesztés kibillenti a protonokat a tengelyükből, majd az impulzus kikapcsolása után a protonok fokozatosan visszaszerzik a longitudinális mágnesezettségüket. Ezt a folyamatot nevezzük longitudinális vagy más néven $\mathrm{T}_{1}$-relaxációnak, amelyet exponenciális görbével lehet jellemezni:

- $\left(T_{1}\right)$, amely az idő függvényében mutatja a longitudinális mágnesezettség újraépülését (1. ábra). Azt az időpontot, amikor az újraépülő longitudinális mágnesezettség elérte az eredeti állapot $63 \%$-át, $T_{1}$-időnek nevezzük. Ez egy szövetspecifikus konstans, amely 150-2000 ms közé eshet. 
- A transzverzális $\left(\mathrm{T}_{2}\right)$ relaxáció ezzel szemben a következőképpen képzelhető el: a protonok különböző irányban rendezetlenül forognak, amelyek összességében egymást kioltják, így a transzverzális síkban nem lesz mágnesezettségük. A rádióhullám-impulzusokkal történő gerjesztés következtében a protonok szinkronban fognak forogni (egy fázisban), ezáltal kialakul a traszverzális síkban is egy mágnesezettség, amely az impulzus kikapcsolása után fokozatosan megszünik. A transzverzális mágnesezettség fokozatos eltünését (fázisvesztés vagy deszinkronizáció) nevezzük $T_{2}$-relaxációnak. A $T_{2}$-relaxációs (csökkenő exponenciális) görbe az idő függvényében mutatja a transzverzális mágnesezettség megszűnését. Amikor a transzverzális mágnesezettség $63 \%$-a eltủnt, az a $T_{2}$-idő. $A T_{2}$-idő a $T_{1}$-időnél jóval rövidebb, 10-150 ms közé eshet.

A rádiófrekvenciás impulzussal való gerjesztést egymás után többször alkalmazzuk, és ismételten detektáljuk a szövetek által leadott jeleket. A rádiófrekvenciás impulzusok között eltelt idő a repetíciós idő, az impulzus és a jeldetektálás közötti idő pedig az echo idő. Mindkettő egy beállítható paraméter, amelyek segítségével a $T_{1}$ - vagy $T_{2}$-relaxáció hatását lehet jobban kiemelni.

Mind a $T_{1}$, mind a $T_{2}$ egy szövetspecifikus idökonstans, amelyekkel jól jellemezhető az egészségestől való eltérés. Hagyományosan ún. $T_{1}$ - és $T_{2}$-súlyozott képalkotást alkalmaztak az MR-vizsgálatokban, amely a fent leírt tulajdonságokat használja ki, de a képen nem a $T_{1}$ - vagy $T_{2}$ idő lesz látható. A különböző szövetek jól differenciálhatók (pl. a zsír $\mathrm{T}_{1}$ ideje rövid, a víz $\mathrm{T}_{1}$ ideje hosszú), azonban csak relatív különbségeket tudunk kimutatni, de a diffúz, enyhe eltérések detektálása igen nehéz. A mappingtechnikák bevezetésével lehetővé vált ezen mágneses tulajdonságok - és ezáltal a szövetek összetételbeli eltérésének - kvantitatív módon való jellemzése is.

Egy további, ritkábban alkalmazott paraméter a $T_{2}{ }^{*}$ ( $T_{2}$-csillag), amely a transzverzális relaxációt írja le a maga tökéletlenségeivel együtt. Ha figyelembe veszszük a mágneses tér egyenetlenségeit, a berendezés tökéletlenségét és magának a betegnek a mágneses térre kifejtett zavaró hatását is, a transzverzális relaxáció gyorsabb lesz, emiatt a $\mathrm{T}_{2}{ }^{*}$-időkonstans rövidebb a $T_{2}$-nél. $A T_{2}$-relaxáció méréséhez használt spin echo módszerek kiküszöbölik a tökéletlenségek jó részét, ezért a $T_{2}$-relaxáció hosszabb ideig tart, mint a $\mathrm{T}_{2}{ }^{*}$. Mivel a $T_{2}{ }^{*}$-ot csak ritkán, speciális kérdésfelvetés estén alkalmazzuk a szív-MR során (hemosziderózis, hemochromatózis), a továbbiakban ezzel részletesen nem foglalkozunk.

\section{$A T_{1-,} T_{2}$ - és extracelluláris (ECV) mapping elve}

$A T_{1}$ - és $T_{2}$-mapping során abszolút értékeket meghatározva, a $T_{1}$ - és $T_{2}$-relaxációs időket a szívizomban pontról pontra detektáljuk, majd ezt egy szürkeskálán (grayscale) vagy tetszőleges színkódolással ellátott színtérképen ábrázoljuk (1. ábra). Így - szemben az imént említett, hagyományos, $T_{1}$ - és $T_{2}$-súlyozott képekkel - kvantitatív kiértékelésre is lehetőség van. Már kismértékű (diffúz vagy fokális) eltérés detektálására is alkalmas, amely a hagyományos $T_{1}$ - és $T_{2}$-súlyozott és LGE-felvételeken nem lenne észlelhetö.

Mivel az alapvető koncepció hasonló, a mapping elméletét a $T_{1}$-mappingen mutatjuk be (1. ábra). Különbözö, egymás után alkalmazott rádiófrekvenciás impulzusokat (inverzió) követően, a T1-relaxáció eltérő időpontjaiban készül kép. Ezeket aztán pontosan egymásra illesztve minden képpontról leolvasható lesz a $\mathrm{T}_{1}$-idő (vagyis amikor a mindenkori képponthoz tartozó szövetrész relaxációja elérte a $63 \%$-ot).

$A T_{1}$-idő mérésére sokféleképpen összeállított szekvencia létezik. A szekvenciákban számos paraméter variálható, például az alkalmazott rádiófrekvenciás impulzusok darabszáma, ideje, egymás közötti szünetek, az, hogy hány szívciklus alatt kerül rögzítésre, mennyi idő telik el a jelkiolvasásig stb. Anélkül, hogy a komplikált fizikai részletekbe belemennénk, a lényeg, hogy annál jobban használható egy szekvencia szív $\mathrm{T}_{1}$-mappingre, minél pontosabban becsüli a $T_{1}$-időt, minél kevésbé zavarja a szívfrekvencia változása vagy a légzés (bár megjegyzendő, hogy ezek a felvételek légzésvisszatartásban készülnek, illetve adott esetben szoftveres korrekcióra is lehetőség van). A jelenleg legszélesebb körben alkalmazott $T_{1}$-szekvenciát, az ún. módosított Look-Locker inversion recovery (MOLLI) szekvenciát Messroghli és munkatársai fejlesztették ki 2004-ben. Ekkor volt elöször lehetőség klinikailag is alkalmazható $T_{1}$-mappingre. Azóta mind a szekvenciák továbbfejlesztése, mind a kiértékelő szoftverek fejlesztése révén egyre pontosabb és egyre szélesebb körben alkalmazható és egyúttal megnyílt a lehetőség a széles körü klinikai kutatások számára is $(5,11-13)$.

A feldolgozást végző szoftverrel kifejezhető a $T_{1}$-idő pontról pontra ms-ban, vagy szegmentumonként vagy szeletenként, vagy akár az egész szívre globálisan számolva. A normálértékek ismeretében az attól való eltérés különböző színekkel ábrázolható, így vizualizálhatók az egészséges és beteg myocardiumrészek. A $T_{1}$-relaxáció megnyúlik fibrózis, ödéma esetén, és csökken a lipidtartalom fokozódása esetén vagy olyan ritka betegségekben, mint a Fabry-kór (2. táblázat).

A $T_{1}$-mapping elvégezhető gadolínium kontrasztanyag adása elött (natív $T_{1}$ ) és azután is (posztkontraszt $T_{1}$ ). Amennyiben mindkettő megtörténik, az aktuális hematokrit ismeretében egy újabb parametrikus térkép, az extracelluláris tér mappingje is elkészíthető (ECV mapping). Ez az extracelluláris tér arányáról szogáltat (akár globálisan, akár lokálisan) információt. Ugyan kontrasztanyag adását igényli, és a teljes szív-MR-protokollt nem rövidíti, hanem inkább megnyújtja, de értékes információt adhat ismeretlen eredetű balkam- 
2. TÁBLÁZAT. $A T_{1^{-},}, T_{2^{-}}, T_{2}{ }^{*}$-idők és az ECV jellegzetes eltérései különböző kórképekben

\begin{tabular}{|c|c|c|c|}
\hline $\begin{array}{l}\text { Para- } \\
\text { méter }\end{array}$ & Csökkent & $\begin{array}{l}\text { Enyhén } \\
\text { emelkedett }\end{array}$ & $\begin{array}{l}\text { Közepesen/na- } \\
\text { gyon emelkedett }\end{array}$ \\
\hline \multirow{3}{*}{ Natív $\mathrm{T}_{1}$} & $\begin{array}{l}\text { Anderson- } \\
\text { Fabry-kór }\end{array}$ & Diffúz fibrózis & Amyloidosis \\
\hline & $\begin{array}{l}\text { Hemoszi- } \\
\text { derózis }\end{array}$ & Heg & Akut gyulladás \\
\hline & Zsír & $\begin{array}{l}\text { Szubakut } \\
\text { gyulladás }\end{array}$ & Akut iszkémia \\
\hline \multirow{3}{*}{ ECV } & Sportszív & Diffúz fibrózis & Amyloidosis \\
\hline & & & Nekrózis (infarktus) \\
\hline & & & Nekrózis, heg \\
\hline \multirow{3}{*}{$\mathrm{T}_{2}$} & $\begin{array}{l}\text { Hemoszi- } \\
\text { derózis }\end{array}$ & $\begin{array}{l}\text { Szubakut } \\
\text { gyulladás }\end{array}$ & Akut gyulladás \\
\hline & Vérzés & & Akut infarktus \\
\hline & & & Akut iszkémia \\
\hline \multirow[t]{2}{*}{$\mathrm{T}_{2}{ }^{*}$} & $\begin{array}{l}\text { Hemoszide- } \\
\text { rózis }\end{array}$ & & \\
\hline & Vérzés & & \\
\hline
\end{tabular}

ra-hipertrófia differenciálásához, mert a miociták hipertrófiája (pl. magas vérnyomás esetén) elkülöníthető lesz az extracelluláris tér megnövekedéséből adódó hipertrófiától (pl. kardiális amyloidosisban), vagy a hipertrófiás cardiomyopathiában jelentkező fibrózistól. $\mathrm{A} \mathrm{T}_{2}$-mapping (nonkontrasztos) a $\mathrm{T}_{2}$-relaxáció különböző fázisaiban készített görbéből számolható, ennek klinikai haszna elsősorban az ödéma kimutatása esetén van (2. táblázat). Nagy jelentősége van tehát az akut szívizom-károsodással járó állapotokban (pl. myocarditis, akut miokardiális infarktus, MINOCA, takotsubo szindróma) (14). A $T_{1}$ - és $T_{2}$-mappinget egyszerre elemezve elkülöníthető egy régebben fennálló károsodás egy akut károsodástól (pl. régi infarktus egy akut infarktustól vagy lezajlott myocarditis egy aktívan fennálló gyulladástól).

\section{Mapping-ajánlások}

2017-ben részletes ajánlás jelent meg a $T_{1^{-}}, T_{2^{-}}, T_{2}{ }^{*}$ és ECV-mapping gyakorlata tekintetében, amelyet a Nemzetközi Szív- és Érrendszeri Mágneses Rezonancia Társaság (SCMR) és az Európai Kardiovaszkuláris Képalkotó Társaság (EACVI) fogalmazott meg. Erre a különböző $T_{1}$-szekvenciák miatt, illetve a jobb standardizálhatóság, reprodukálhatóság és a minőség javítása céljából volt szükség (15).

A közlemény többek között ajánlásokat tesz a terminológiára, a preferálandó szekvenciákra, klinikai indikációkra, síkok tervezésére, minőség-ellenőrzésre, hibajavításra, normálértékekre, ábrázolásokra, kiértékelésre, leletezésre. A mapping alkalmazását kifejezetten ajánlják vastárolási betegségek, Fabry-kór vagy amyloidosis kardiális érintettségének vizsgálatában, illetve myocar- ditis gyanúja esetén, ezekben az esetekben a mapping ugyanis igazoltan hasznos additív információval szolgál (3. táblázat). Javasolt továbbá valamennyi szívelégtelen betegen végzett szív-MR-vizsgálatot mappinggel kiegészíteni a feltételezett additív diagnosztikus és prognosztikus információk miatt.

Érdemes továbbá kiemelni, hogy minden szív-MR-centrum számára helyi normálértékek felállítását javasolják. Elegendő számú és megfelelő kormegoszlású, egészséges egyénen végzett vizsgálatokból az alkalmazott normálérték-tartományt az átlag \pm 2 szórás tartományban javasolt meghatározni. A mappinggel napi szinten nem foglalkozó kardiológus számára az ajánlás legfontosabb üzenete a klinikai indikációk listája, amelyet a 3. táblázat foglal össze az idézett ajánlás alapján.

\section{Klinikai alkalmazás és példák}

$A T_{1}-, T_{2^{-}}, T_{2}{ }^{*}$ - és ECV-mapping jellegzetes eltéréseit különböző kórképekben a 2. táblázat foglalja össze, a klinikai indikációkat a 3. táblázat szemlélteti.

\section{Mapping a Városmajori Szív- és Érgyógyászati Klinikán}

A Városmajori Szív- és Érgyógyászati Klinikán 2019 májusa óta több mint $600, T_{1}$ - és $T_{2}$-mappinget is magába foglaló szív-MR-vizsgálatot végeztünk. A következő diagnózisok során használtuk sikerrel mind a $\mathrm{T}_{1}$ mind a $\mathrm{T}_{2}$-mappingtechnikát, az irodalmi adatokhoz hasonlóan hasznos információkkal kiegészítve a hagyományos vizsgálatot: myocarditis $(n=61)$, hipertrófiás cardiomyopathia $(n=73)$, amyloidosis $(n=16)$, takotsubo szindróma $(n=4)$, Fabry-kór $(n=2)$, normálleletek $(n=23)$, illetve kontrollok $(n=53)$. További indikációk, diagnózisok, amelyek során a mapping alkalmazásra került, ám annak klinikai jelentősége még kevésbé kidolgozott, és jelenleg is futó tanulmányok kapcsán folyamatban van:

\section{TÁBLÁZAT. Mapping klinikai indikációi szakértői ajánlások} alapján

\begin{tabular}{|l|l|}
\hline \multirow{2}{*}{$\begin{array}{l}\text { Igazoltan hasznos } \\
\text { (ajánlott) }\end{array}$} & Myocarditis \\
\hline & Amyloidosis \\
& Anderson-Fabry-kór \\
\hline & Vastárolási betegség \\
\hline Cardiomyopathiák \\
\hline Szívelégtelenség \\
\hline Valószínűleg hasznos \\
(megfontolandó) & Akut/krónikus szívinfarktus \\
\hline & Iszkémia \\
\hline Gyanított rejekció HTX után \\
\hline Sportszív \\
\hline (para)kardiális térfoglaló folyamatok
\end{tabular}


MINOCA $(n=19), \operatorname{DCM}(n=53), \operatorname{HTX}(n=63)$, viabilitás kérdése ISZB esetén ( $n=77)$, sportolók $(n=101)$. Bizonyos diagnózisok esetén a mapping additív értéke a hagyományos kontrasztanyagos MR-hez képest egyelőre kérdéses: noncompact cardiomyopathia $(n=20)$, aritmogén jobb kamrai cardiomyopathia $(n=36)$, aortasztenózis $(n=3)$. A fenti sorokban szerepeltetett esetszámok 2019 májusa és a cikk közlése között eltelt időre vonatkoznak.

Jelen közlemény első szerzője korábban a Heidelbergi Egyetem Kardiológiai Klinikáján többezres beteganyagon végzett $T_{1} / T_{2}$-mappinget, és gyüjtött abban tapasztalatot.

A következőkben néhány, a Városmajori Szív- és Érgyógyászati Klinikáról származó példán keresztül mutatjuk be a $T_{1}$ - és $T_{2}$-mapping klinikai alkalmazását. Siemens Aera 1,5 teslás szkenneren (Siemens, Erlangen, Németország) az 5(3)3 MOLLI szekvenciával végeztünk $T_{1}$-mappinget, amelynek kiértékelését a Medis 3.1 (Medis medical imaging systems, Leiden, Hollandia) és CVI42 V 5.11 (Circle Cardiovascular Imaging, Calgary, Canada) szoftverekkel végeztük.

\section{Normál lelet}

A 2. ábrán egy egészséges önkéntes normál myocardium szürkeskálás (grayscale) és színkódolt $T_{1}$-mappingje, valamint színkódolt $\mathrm{T}_{2}$-mappingje látható rövid tengelyű síkban. A CVI42 kiértékelő szoftver lehetőséget ad individuális színkódolás megválasztására. A kontrollcsoport $(n=53)$ adatai alapján a következőképpen alakultak a helyi normálértékek. $T_{1}=961 \pm 23 \mathrm{~ms}$ és $\mathrm{T}_{2}=43,8 \pm 2,3 \mathrm{~ms}$ (átlag \pm szórás, CVI42). Ennek alapján, a nemzetközi ajánláshoz kapcsolódóan a következőképpen került meghatározásra a helyi normálérték-tartomány: $T_{1}$ esetében 915 ms-tól 1007 ms-ig, és $T_{2}$ esetében 39,2 ms-tól 48,4 ms-ig.

A helyi normálértékek ismeretében tetszőlegesen állíthatóak be a színek normál, átmeneti és kóros tartományokra. A színskálát minden esetben centrumonként az adott szkenner normálértékei szerint kell beállítani.
Jelen esetben a natív $\mathrm{T}_{1}$-mappingen zöld jelöli a normál $\mathrm{T}_{1}$-tartományt, kék a csökkent $\mathrm{T}_{1}$-időt, sárga az emelkedett, sötétpiros/bordó a nagymértékben emelkedett $T_{1}$ et kódolja. A vér $T_{1}$-ideje magas, ezért a képen bordón jelenik meg. A trabekulák között az izom-vér határon a sárga sáv a trabekulák közé keveredett vér miatt jelez emelkedett értéket.

Részben ismételve a korábban leírtakat, rendkívül fontos a nagyon jó minőségű nyers képanyag, illetve a jó minőségü számított mapping képe, ugyanis kisebb hibák is téves interpretációhoz vezethetnek (általában álpozitív eredményt okozva). Fontos, hogy ne legyenek műtermékek a mappingen, ne legyenek légzésből vagy gyors/irreguláris szívritmusból adódó elcsúszások, ugyanis ilyen esetben a vér-myocardium vagy myocardium-pericardium határa csak pontatlanul határozható meg. Ilyenkor ún. „partial volume” effektus léphet fel, pl. magas $T_{1}$-idejű vér „keveredik” a szívizom trabekulái közé vagy alacsony $\mathrm{T}_{1}$-idejü epikardiális zsír „keveredik” a szívizomba. Mindkettő nagymértékben meghamisíthatja a szívizomra számolt $\mathrm{T}_{1}$-időt. Ezeket elkerülendő fontos, hogy a mapping kiértékelése csak a kompakt myocardiumban történjen (a trabekulákat „levágjuk”) (16-20).

\section{Hipertrófiás cardiomyopathia (HCM)}

A hipertrófiás cardiomyopathia MR-képére jellegzetes a diffúz fibrózis mellett a bal kamra-jobb kamra inzerciós zónáknál kifejezettebb fibrózis, amely ezeken a pontokon erősebb fokális késői kontrasztanyag-halmozást (LGE) okoz (16, 21-25). Enyhébb és diffúz fibrózis detektálása LGE alapján nehéz lehet, mert a késői halmozás kiértékelhetősége a térbeli heterogenitástól is függ. Továbbá nincs validált módszer a diffúz LGE kvantifikálására. Mind HCM-ben, mind DCM-ben gyakran jelen lehet a patognómikus fibrózisminták mellett diffúz fibrózis is. Ennek detektálására a $T_{1}$-mapping előnyösebb lehet, mint az LGE, ugyanis a natív $T_{1}$-mappinggel nemcsak a fokális fibrózisokat, hanem enyhébb, diffúz elváltozásokat is észlelhetünk (16).

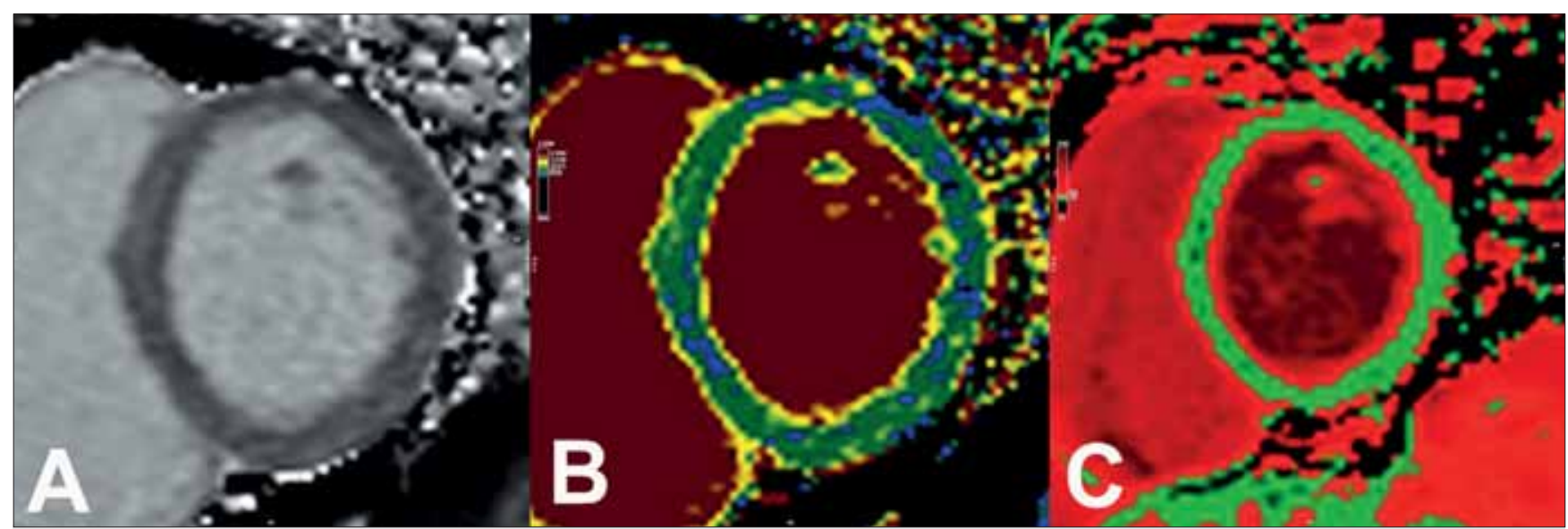

2. ÁBRA. Normál lelet. A: Normál natív $T_{1}$-mapping (szürkeskálás, grayscale); B: Normál natív $T_{1}$-mapping színkódolva (nincsen fokális vagy diffúz fibrózis); $C$ : Normál $\mathrm{T}_{2}$-mapping színkódolva (nincs ödéma) 


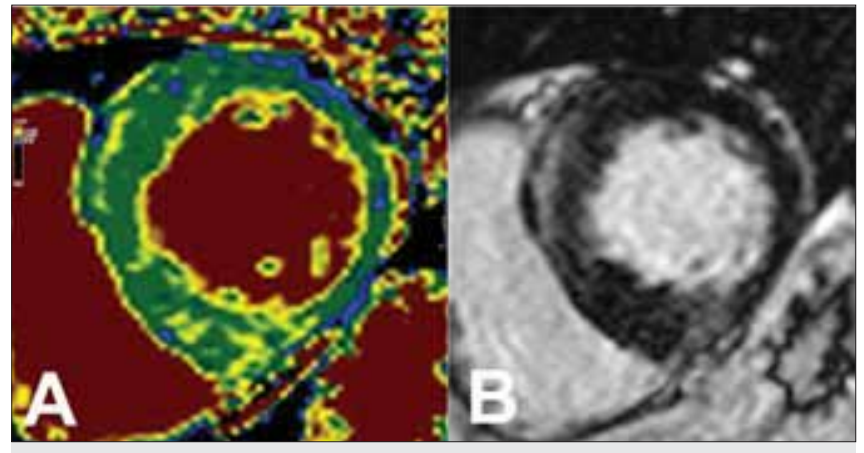

3. ÁBRA. HCM. A: Színkódolt T1-mapping a bazális rövidtengelyú síkban (az inzerciós pontokon fokális fibrózis látható). B: LGE a bazális rövidtengelyú síkban (az inzerciós pontokon fokális fibrózis látható, amely teljesen megfelel a natív $T_{1}$-mappingen látott lokalizációval)

A 3. ábrán jól felismerhető a fokális késői kontrasztanyag-halmozás (LGE). Natív $T_{1}$-mapping alkalmazásával, színkódolt térképen ábrázolva hasonló mintázatot fedezhetünk fel, a 3. ábrán látható példán jól felismerhető a HCM képe. $A T_{1}$-idők abszolút értékben való megadása (szegmentálisan) a helyi normálértékek ismeretében a diffúz enyhe fibrózist is mutathatja az LGE által detektált fibrotikus területeken kívül is.

\section{Amyloidosis}

Az amyloidosis mindkét fő formájában (immunglobulin könnyülánc-eredetü „AL” amyloidosis, illetve transztiretin „ATTR” amyloidosis) a kardiális érintettség meghatározza a terápiás döntéseket és a prognózist is. A szív-MR-vizsgálat rendkívül értékes információkkal szolgál ezekben a betegekben. Korai kardiális érintettség esetén szubendokardiális, majd diffúz transzmurális és a jobb kamrai myocardiumot is magába foglaló késői halmozást mutat $(4$. ábra) $(26,27)$. Leírtak atípusos megjelenésű késői halmozásokat is, továbbá a súlyosabban károsodott vesefunkció - amely gyakori velejárója az előrehaladott stádiumú amyloidosisnak

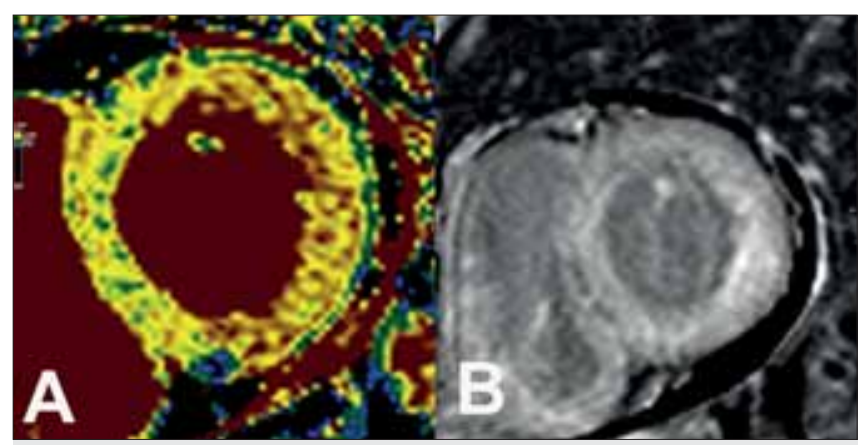

4. ÁBRA. Kardiális amyloidosis. A: Színkódolt $T_{1}$-mapping, bazális rövidtengelyű sík (diffúz és igen kifejezett fibrózis látható, $\mathrm{T}_{1}$-idő a bazális síkban 1125 ms; normáltartomány 915-1007 ms). B: LGE, rövid tengely, bazálisan (diffúz transzmurális késői halmozás látható, a jobb kamra is érintett, és perikardiális fluidum is jelen van)
- limitálja a gadolíniumtartalmú MR-kontrasztanyag alkalmazását. Mint fentebb, a mappingajánlásoknál említettük, a natív $\mathrm{T}_{1}$-mappingnek diagnosztikus jelentősége van a kardiális amyloidosis felfedésében. Korai stádiumban pedig - magasabb szenzitivitása miatt - az LGE-vel szemben is előnyben részesitendő (az elérhetőség függvényében mindkét módszer alkalmazása javasolt) (28-30). Az 4. ábrán kardiális amyloidosis képe látható.

\section{Fabry-kór}

Egy ritka, X-kromoszómához kötött lizoszomális tárolási betegség az Anderson-Fabry-kór, amely szintén balkamra-hipertrófiával járhat. Patofiziológiai háttere a glikoszfingolipidek intracelluláris akkumulációja. $\mathrm{Az}$ emelkedett lipidtartalom miatt, mint fentebb már tárgyaltuk, a $\mathrm{T}_{1}$-relaxációs idő csökkent. A betegség kardiális érintettsége esetén a balkamra-hipertrófiához csökkent $T_{1}$ társul (szemben a legtöbb egyéb, hipertrófiához vezető kórképpel), ez tehát diagnosztikus értékü. $A$ korai stádium kimutatásában ezért a $\mathrm{T}_{1}$-mappingnek igen nagy a jelentősége (31). A 5. ábrán egy Fabry-kóros beteg $\mathrm{T}_{1}$-mappingje látható (rövidtengelyü sík).

\section{További klinikai fellhasználások}

Mind akut szívinfarktusban, mind akut myocarditisben megjelenik a kisebb-nagyobb kiterjedésű miokardiális ödéma, amely megemelkedett szöveti víztartalommal jár együtt. Ennek következtében, az ép myocardiumhoz képest a natív $T_{1}$-idő és a $T_{2}$-idő megnyúlik, a posztkontraszt $T_{1}$-idö pedig csökken $(32,33)$. Extracelluláris ödéma esetén az extracelluláris tér is megnő, amely ECV-mapping használatával jól mérhető. A leggyakoribb klinikai diagnózisok, amelyek akut ödémával járnak az akut miokardiális infarktus, MINOCA, akut myocarditis, illetve stresszindukált takotsubo szindróma $(14,34,35)$. A hagyományos, $T_{2}$-súlyozott felvételekkel szemben a mappingtechnika előnyösnek

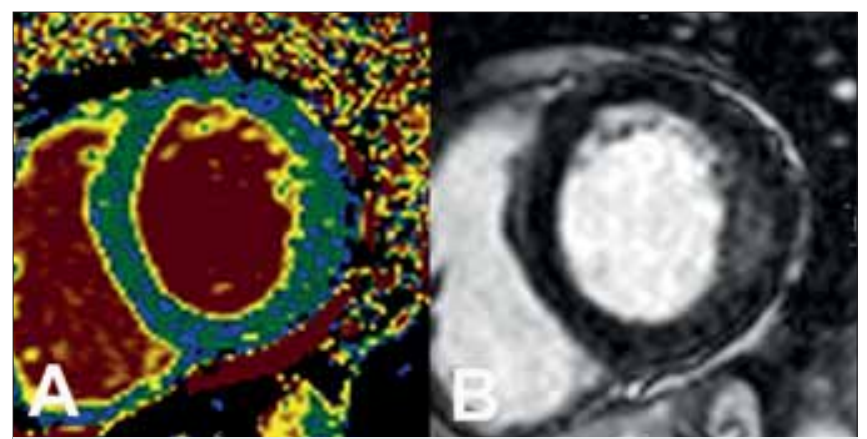

5. ÁBRA. Fabry-kór. A: Natív, színkódolt $T_{1}$-mapping (diffúzan, laterális túlsúllyal csökkent T1-idő: 895 ms, amelyet a számos kékes folt jelez a myocardiumban, amivel jelen esetben a normál alatti $T_{1}$-idők vannak kódolva; normál tartomány 915-1007 ms). B: LGE, inferolaterálisan intramiokardiális késői halmozás látható 


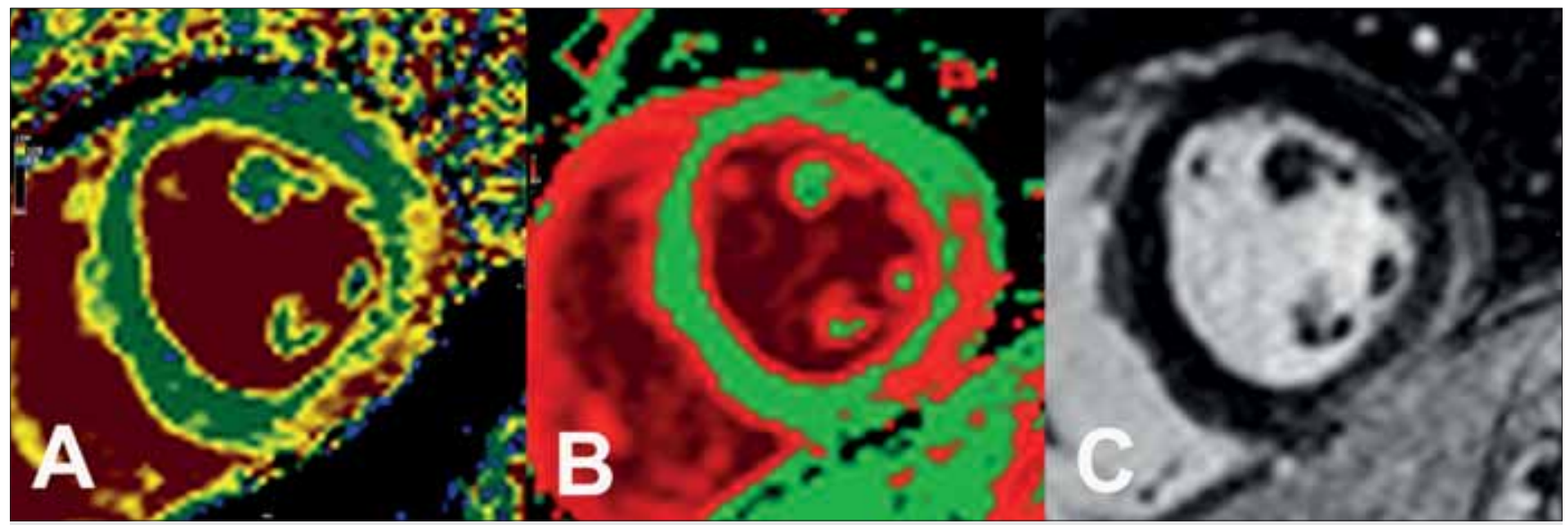

6. ÁBRA. Akut myocarditis. A: Színkódolt $\mathrm{T}_{1}$-mapping a bazális rövidtengelyű síkban (inferolaterálisan epikardiálisan magas $\mathrm{T}_{1}$ látható - 1200 ms; normáltartomány 915-1007 ms). B: Színkódolt $T_{2}$-mapping a bazális rövidtengelyű síkban (inferolaterálisan epikardiálisan magas $T_{2}$ látható - 65 ms; normáltartomány 39-48 ms). C: LGE a bazális rövidtengelyű síkban (inferolaterális epikardiális LGE látható)

bizonyult a szívizom-károsodás detektálásában mind STEMI, mind NSTEMI esetében (34). A mapping továbbá szenzitívebb a krónikus, illetve szubklinikus gyulladás észlelésében is (2-3. táblázat). A 6 . ábrán egy akut myocarditises beteg $\mathrm{T}_{1}$ - és $\mathrm{T}_{2}$-mappingje látható.

Az aortasztenózisban jelentkező emelkedett utóterhelés (fokozott végdiasztolés nyomás) a szívizomban diffúz fibrózishoz vezet. $T_{1}$-mappinggel ez jól kimutatható és szövettani adatokkal korreláltatható (36). Súlyos aortasztenózisban a fibrózis mértékének prognosztikus szerepe van, ezért ezen betegekben a $\mathrm{T}_{1}$-mapping fontos vizsgálómódszer lehet.

Az aortasztenózishoz hasonlóan a magasvérnyomás-betegség is a bal kamra utóterhelésének növekedéséhez vezet, a szívizom fibrózisát és hipertrófiáját okozza (37). A $T_{1}$-mapping segíthet a magas vérnyomás okozta hipertrófia egyéb specifikus okoktól (HCM, amyloidosis, Fabry-kór) való elkülönítésében.

\section{Következtetések}

A mappingtechnikák klinikai kardiológiai alkalmazása a szív-MR-vizsgálatok során mintegy másfél évtizede indult, és azóta folyamatos fejlesztéseken megy keresztül, új fejezetet nyitva ezzel a myocardium betegségeinek koraibb és pontosabb feltárására. A jövő feladata lesz többek között a mapping szélesebb hozzáférhetőségének megteremtése, diagnosztikus és prognosztikus értékeinek kidolgozása, a diagnosztikus láncba való integrálása, valamint a kontrasztanyagmentes és gyorsabb MR-protokollok validálása. Mindezek tekintetében nagy lehetőség és feladat áll a szív-MR iránt érdeklődő kutatók előtt. A Városmajori Szív- és Érgyógyászati Klinika is számos helyi és nemzetközi kooperációs projekttel támogatja ezt a folyamatot.

\section{Nyilatkozatok}

A vizsgálatban részt vevő betegek írásbeli hozzájárulásukat adták a vizsgálat elvégzéséhez.

A szerzők kijelentik, hogy a tanulmány megírásával kapcsolatban nem áll fenn velük szemben pénzügyi vagy egyéb lényeges összeütközés, összeférhetetlenségi ok, amelyek befolyásolhatják a tanulmányban bemutatott eredményeket, az abból levont következtetéseket vagy azok értelmezését.

\section{Irodalom}

1. Bruder O, et al. European Cardiovascular Magnetic Resonance (EuroCMR) registry-multinational results from 57 centers in 15 countries. J Cardiovasc Magn Reson 2013; 15: 9. doi: 10.1186/1532429X-15-9

2. Thygesen $\mathrm{K}$, et al. Fourth universal definition of myocardial infarction (2018). Eur Heart J 2019; 40(3): 237-269. doi: 10.1093/eurheartj/ehy 462

3. Bing R, Dweck MR. Myocardial fibrosis: why image, how to image and clinical implications. Heart 2019; 105(23): 1832-840.

4. Steen H. Diagnostische Verfahren und Bildgebung. Kardiologie up2date 2012; 08(03): 233-252.

5. Messroghli DR, et al. Modified Look-Locker inversion recovery (MOLLI) for high-resolution T1 mapping of the heart. Magn Reson Med 2004; 52(1): 141-6.

6. Nadjiri J, et al. Evaluation of a shortened cardiac MRI protocol for left ventricular examinations: diagnostic performance of T1-mapping and myocardial function analysis. BMC Med Imagine 2019; 19(1): 57. doi: 10.1186/s12880-019-0358-9

7. Puntmann VO, et al. T1 Mapping in Characterizing Myocardial Disease: A Comprehensive Review Circ Res 2016; 119(2): 277-99. doi: 10.1161/CIRCRESAHA.116.307974

8. Ridgway JP. Cardiovascular magnetic resonance physics for clinicians: part I. J Cardiovasc Magn Reson 2010; 12: 71. doi: 10.1186/1532-429X-12-71

9. Ripley DP, et al. Cardiovascular magnetic resonance imaging: what the general cardiologist should know. Heart 2016; 102(19): 1589-603. doi: 10.1136/heartjnl-2015-307896

10. Valbuena-Lopez SR. Hinojar, Puntmann VO. Cardiovascular 
Magnetic Resonance in Cardiology Practice: A Concise Guide to Image Acquisition and Clinical Interpretation. Rev Esp Cardiol (Engl Ed) 2016; 69(2): 202-10. doi: 10.1016/j.rec.2015.11.011

11. Kellman $P$, Arai AE, Xue, H. T1 and extracellular volume mapping in the heart: estimation of error maps and the influence of noise on precision. J Cardiovasc Magn Reson 2013; 15: 56. doi: 10.1186/1532429X-15-56

12. Kellman $P$, Hansen MS. T1-mapping in the heart: accuracy and precision. J Cardiovasc Magn Reson 2014; 16: 2. doi: 10.1186/1532429X-16-2

13. Messroghli DR, et al. Human myocardium: single-breath-hold MR T1 mapping with high spatial resolution-reproducibility study. Radiology 2006; 238(3): 1004-12.

14. Chetrit $M$, Friedrich $M G$. The unique role of cardiovascular magnetic resonance imaging in acute myocarditis. F1000Res 2018; 7. doi: 10.12688/f1000research.14857.1

15. Messroghli DR, et al. Clinical recommendations for cardiovascular magnetic resonance mapping of T1, T2, T2* and extracellular volume: A consensus statement by the Society for Cardiovascular Magnetic Resonance (SCMR) endorsed by the European Association for Cardiovascular Imaging (EACVI). J Cardiovasc Magn Reson 2017; 19(1): 75. doi: 10.1186/s12968-017-0389-8

16. Dass $S$, et al. Myocardial tissue characterization using magnetic resonance noncontrast $\mathrm{t} 1$ mapping in hypertrophic and dilated cardiomyopathy. Circ Cardiovasc Imaging 2012; 5(6): 726-33. doi: 10.1161/CIRCIMAGING.112.976738.

17. Gottbrecht M, Kramer CM, Salerno M. Native T1 and Extracellular Volume Measurements by Cardiac MRI in Healthy Adults: A Meta-Analysis. Radiology 2019; 290(2): 317-326. doi: 10.1148/radiol.2018180226.

18. Granitz $\mathrm{M}$, et al. Comparison of native myocardial T1 and T2 mapping at $1.5 \mathrm{~T}$ and $3 \mathrm{~T}$ in healthy volunteers: Reference values and clinical implications. Wien Klin Wochenschr 2019; 131(7-8): 143-155. doi: 10.1007/s00508-018-1411-3.

19. Kammerlander AA, Mascherbauer J. What is normal? A central question in the application of CMR mapping techniques. Wien Klin Wochenschr 2019; 131(7-8): 141-142. doi: 10.1007/s00508-0191490-9

20. Rosmini $\mathrm{S}$, et al. Myocardial native $\mathrm{T} 1$ and extracellular volume with healthy ageing and gender. Eur Heart $\mathrm{J}$ Cardiovasc Imaging 2018; 19(6): 615-621. doi: 10.1093/ehjci/jey034

21. Hinojar R, et al. T1 Mapping in Discrimination of Hypertrophic Phenotypes: Hypertensive Heart Disease and Hypertrophic Cardiomyopathy: Findings From the International T1 Multicenter Cardiovascular Magnetic Resonance Study. Circ Cardiovasc Imaging 2015; 8(12). doi: 10.1161/CIRCIMAGING.115.003285

22. Kato S, et al. Myocardial Native T1 Time in Patients With Hypertrophic Cardiomyopathy. Am J Cardiol 2016; 118(7): 1057-62. doi: 10.1016/j.amjcard.2016.07.010.

23. McKenna WJ, Maron BJ, Thiene G. Classification, Epidemiology, and Global Burden of Cardiomyopathies. Circ Res 2017; 121(7):
722-730. doi: 10.1161/CIRCRESAHA.117.309711

24. Puntmann VO, et al. Native T1 mapping in differentiation of normal myocardium from diffuse disease in hypertrophic and dilated cardiomyopathy. JACC Cardiovasc Imaging 2013; 6(4): 475-84. doi: 10.1016/j.jcmg.2012.08.019

25. Swoboda PP, et al. Role of T1 Mapping in Inherited Cardiomyopathies. Eur Cardiol 2016; 11(2): 96-101. doi: 10.15420/ ecr/2016:28:2

26. Maceira AM, et al. Cardiovascular magnetic resonance in cardiac amyloidosis. Circulation 2005; 111(2): 186-93. doi: 10.1186/1532429X-10-54

27. Maceira $A M$, et al. Cardiovascular magnetic resonance and prognosis in cardiac amyloidosis. J Cardiovasc Magn Reson 2008; 10: 54. doi: 10.1186/1532-429X-10-54

28. Fontana $M$, et al. Native T1 mapping in transthyretin amyloidosis. JACC Cardiovasc Imaging 2014; 7(2): 157-65. doi: 10.1016/j. jcmg.2013.10.008

29. Karamitsos TD, Papanastasiou CA. Cardiac Magnetic Resonance T1 Mapping for Cardiac Amyloidosis: The Best Way Forward. JACC Cardiovasc Imaging, 2020; 13: 81-82 doi: 10.1016/j. jcmg.2019.04.011.

30. Karamitsos TD et al. Noncontrast T1 mapping for the diagnosis of cardiac amyloidosis. JACC Cardiovasc Imaging 2013; 6(4): 48897. doi: 10.1016/j.jcmg.2012.11.013

31. Thompson $\mathrm{R}$, et al. T(1) mapping with cardiovascular MRI is highly sensitive for Fabry disease independent of hypertrophy and sex. Circ Cardiovasc Imaging 2013; 6(5): 637-45. doi: 10.1161/CIRCIMAGING.113.000482.

32. Messroghli DR, et al. Myocardial T1 mapping: application to patients with acute and chronic myocardial infarction. Magn Reson Med 2007; 58(1): 34-40.

33. Williams ES, et al. Prolongation of proton spin lattice relaxation times in regionally ischemic tissue from dog hearts. J Nucl Med 1980; 21(5): 449-53.

34. Dall'Armellin E, et al. Cardiovascular magnetic resonance by non contrast T1-mapping allows assessment of severity of injury in acute myocardial infarction. J Cardiovasc Magn Reson 2012; 14: 15. doi: 10.1186/1532-429X-14-15

35. Ferreira VM, et al. T(1) mapping for the diagnosis of acute myocarditis using CMR: comparison to T2-weighted and late gadolinium enhanced imaging. JACC Cardiovasc Imaging 2013; 6(10): 1048-1058. doi: 10.1016/j.jcmg.2013.03.008

36. Lee SP, et al. Assessment of diffuse myocardial fibrosis by using MR imaging in asymptomatic patients with aortic stenosis. Radiology 2015; 274(2): 359-69. doi: 10.1148/radiol.14141120

37. Treibel TA, et al. Extracellular volume quantification in isolated hypertension - changes at the detectable limits? J Cardiovasc Magn Reson 2015; 17: 74. doi: 10.1186/s12968-015-0176-3

38. Haaf $P$, et al. Cardiac T1 Mapping and Extracellular Volume (ECV) in clinical practice: a comprehensive review. J Cardiovasc Magn Reson 2016; 18(1): 89. 